\title{
REWOLUCJA SEKSUALNA I DZIECI
}

\section{Streszczenie}

W narracji o konsekwencjach i wpływach tzw. rewolucji seksualnej $1968 \mathrm{r}$. wspomnieć należy również o dzieciach, które niekiedy były oficjalnie systemowo rewolucjonizowane. Pod koniec lat 60. jako programowy efekt niemieckiego ruchu z 1968 r. było wyzwolenie seksualne dzieci pod egidą Berlińskiego Instytutu Psychologii. W praktyce zakładano ośrodki, których celem miało być wychowanie pokonujące zahamowania seksualne dążąc do stworzenia klimatu, w którym nawet pedofilia uznawana była za postępową. Niektóre ustroje polityczne po $1968 \mathrm{r}$. wpływały na rozumienie seksualności. Seksuologowie niemieccy lat 70. i 80. mieli realny wpływ na badaczy tych dziedzin z innych krajów. Tak radykalny efekt rewolucji seksualnej, który dzisiaj zdaje się być świadomie pomijany, niewątpliwie wpływał na pojęcie wychowania, rodziny, seksualności i płci. Konsekwencje są widoczne po dzień dzisiejszy.

Słowa kluczowe: rewolucja seksualna, seksualność, wychowanie, edukacja

* Patryk Hałajczak - Wydział Studiów Społecznych, Wyższa Szkoła Bezpieczeństwa w Poznaniu. Adres korespondencyjny: patryk.halajczak@o2.pl. ORCID: 0000-0001-8657-3587. 
Ursula Besser była poważnym zachodnim politykiem niemieckim․ Od $1967 \mathrm{r}$. do 1985 r. także członkiem Berlińskiej Izby Reprezentantów, przewodniczącą Komitetu Naukowego oraz członkiem Rady Powierniczej Wolnego Uniwersytetu w Berlinie. Wiosną 1970 r. znalazła nieznaną dla niej teczkę przed drzwiami swojego mieszkania ${ }^{2}$.

Czas i okoliczności podrzucenia owej paczki przypadły na wydarzenia, kiedy to wojowała rewolucja, znana nam dzisiaj jako seksualna. Besser - wdowa po oficerze poległym podczas II wojny światowej - należała do tych sił, które ostro sprzeciwiały się radykalnym zmianom głoszonym przez owych rewolucjonistów ${ }^{3}$. Zaledwie trzy lata wcześniej została wybrana do Berlińskiego Parlamentu, zaś jej własna partia (CDU) wyznaczyła właśnie ją, doktora filologii germańskiej i romańskiej, do komisji edukacyjnej, gdzie szybko zyskała reputację zarówno bezpośredniej, jak i bojowej.

Wróćmy jednak to tajemniczej teczki. Zawierała stosy papieru - codzienne raporty na temat pracy edukacyjnej w centrum szkolnym w berlińskiej dzielnicy Kreuzberg, gdzie popołudniami opiekowano się piętnaściorgiem dzieci w wieku od 8 do 14 lat. Pierwszy raport datowany był na 13 sierpnia 1969 r., a ostatni na 14 stycznia 1970 r. ${ }^{5}$ Już nawet pobieżny przegląd tego materiału ujawnił, że praca edukacyjna w tym szkolnym centrum Rote Freiheit (Czerwona Wolność) była dość niekonwencjonalna. Celem ośrodka było ukształtowanie podopiecznych w „osobowości socjalistyczne”, a ich misja edukacyjna wykraczała daleko poza tę ogólnie nadzorowaną. Program obejmował m.in. ćwiczenia praktyczne mające na celu wyrobienie w uczniu właściwej postawy na temat chociażby ówczesnej sytuacji w Wietnamie. Miała pomóc w tym innowacyjna zabawa edukacyjna, chociażby taka jak ,walki uliczne”, w której dzieci były podzielone na protestujących studentów i walczących z nimi policjantów. ${ }^{6}$

1 Artykuł powstał na postawie referatu wygłoszonego podczas II Ogólnopolskiej Konferencji Naukowej „Miłość i seksualność po rewolucji obyczajowej 1968 roku” w Uniwersytecie Kardynała Stefana Wyszyńskiego w Warszawie 22 maja 2019 roku.

2 W. Becker, U. Leisner, Man musste blonde weiber haben „Der Spigel“ 1970, nr 16, S. 99.

Tamże.

4 J. Fleischhauer, W. Hollersen, Kuck mal, meine Vagina „Der Spigel” 2010, nr 25, s. 40.

5 Tamże, s. 41.

6 Tamże, s. 42. 


\section{Stosunek pantomimiczny}

Podrzucone notatki wychowawców wskazywały również, że kładli oni bardzo duży nacisk na edukację seksualną. Niemal każdego dnia uczniowie grali w gry polegające na zdejmowaniu ubrań, wspólnym czytaniu magazynów pornograficznych i stosowaniu pantomimy o wyraźnych konotacjach aktów seksualnych?

Według zapisków takie ,ćwiczenie seksu” zostało przeprowadzone 11 grudnia 1969 r. i 14 stycznia 1970 r. Wpis nauczyciela zrobiony 26 listopada 1969 r. brzmi: „Ogólnie rzecz biorąc, leżąc na podłodze wielokrotnie prowokowaliśmy otwarcie lub w ukryty sposób, seksualne insynuacje, które następnie zostały wyrażane w pantomimach, które Kurt i Rita wykonali razem na niskim stole (jako scena) przed nami" $"$.

Dzięki temu podrzuconemu materiałowi po raz pierwszy przedstawiono szerszej opinii publicznej produkt uboczny tzw. rewolucji seksualnej z 1968 r., a mianowicie wyzwolenie seksualne dzieci. Besser przekazała raporty redaktorowi gazety Der Abend, która opublikowała fragmenty tego materiału?

7 kwietnia 1970 r. parlament w Berlinie (wszystko dzieje się w zachodniej części miasta) zajął się tematem tego centrum. Jak się okazało to Instytut Psychologii Wolnego Uniwersytetu w Berlinie stał całym sobą za tą inwestycją. Nawet więcej bo to właśnie ten Instytut założył tę placówkę i zapewnił nauczycielom, którzy tam pracowali pracę i warunki do jej wykonywania ${ }^{10}$. Wysoce prawdopodobne, że to zaniepokojony pracownik podrzucił raporty przy drzwiach Besser.

Kilka dni później po tym wydarzeniu Besser osobiście złożyła wizytę w Instytucie Psychologii w dzielnicy Berlina Dahlem gdzie mieściło się owo centrum. Chciała samodzielnie na nie spojrzeć. Jak potem opisywała, w piwnicy odkryła dwa pokoje oddzielone dużym, jednokierunkowym lustrem. W jednym z pokoi był materac i umywalka a obok na ścianie rząd wiszących kolorowych myjek. Zapytała oprowadzającego ją pracownika co to za miejsce a ten powiedział

7 T. Teo, Klaus Holzkamp and the Rise and Decline of German Critical Psychology, „History of Psychology” 1998, nr 1, s. 238.

8 J. Fleischhauer, W. Hollersen, Kuck mal, meine Vagina, „Der Spigel” 2010, nr 25, s. $42-43$.

9 Tamże.

10 T. Teo, Klaus Holzkamp and the Rise and Decline of German Critical Psychology, „History of Psychology” 1998, nr 1, s. 240. 
jej, że piwnica była wykorzystywana jako „stacja obserwacyjna” do badania zachowań seksualnych u dzieci" ${ }^{11}$.

Od tego czasu centrum zostało zlikwidowane i zapadło w zapomnienie ${ }^{12}$. Członkowie ruchu z $1968 \mathrm{r}$. i ich następcy zostali uwikłani w dziwną obsesję na punkcie seksualności dzieci. Jest to rozdział historii ruchu, o którym rzadko się wspomina w relacjach z tamtej epoki. Można odnieść wrażenie, że w tej kwestii weterani rewolucji seksualnej z 1968 roku i lat następnych ulegli dzisiaj dość ostrej amnezji. A analiza tego aspektu omawianej rewolucji wydaje się być zasadne.

\section{Możliwość seksu z dziećmi}

W dzisiejszej debacie na temat wykorzystywania seksualnego dzieci i młodzieży jednym z elementów jest czasami pewne zamieszanie co do tego, gdzie należy wyznaczyć granicę $w$ jakichkolwiek interakcjach $\mathrm{z}$ dziećmi. To zamieszanie nie ogranicza się do Kościoła katolickiego. W tak zwanych kręgach postępowych erotyzacja dzieci i stopniowe obniżanie tabu mogło zacząc się od rewolucji seksualnej końca lat 60 ., a na przytaczanych przeze mnie przykładach można zauważyć, że była to zmiana, która w radykalnych przypadkach dopuszczała nawet seks z dziećmi.

Zdają się to potwierdzać również incydenty w szkole Odenwald w zachodnim stanie Hesji, które pokazały, że istnieje związek między wezwaniami do reform ruchu z 1968 r. a usunięciem zahamowań seksualnych.

Ta prywatna świecka szkoła była w latach 70., 80. i 90. XX wieku miejscem perwersyjnych praktyk lewicowych pedagogów. Ich ofiarą padło ponad 100 uczniów. Po tym, jak w 1972 r. były ewangelicki pastor przejął kierownictwo Odenwaldschule (OSO), uczniowie byli w nocy regularnie budzeni przez nauczycieli głaszczących ich po genitaliach. Niektóre dzieci, naogół w wieku od 8 do 11 lat, wyznaczano na tzw. weekendy na ,seksualnych usługodawców” i zmuszano do seksu oralnego. Niektórzy pedagodzy wręcz oferowali chłopców odwiedzającym ich gościom. Nauczyciele i wychowawcy bili dzieci, podawali im narkotyki i alkohol. Sam wychowawca Becker miał osobiście molestować co najmniej 86 uczniów ${ }^{13}$.

Sama Odenwaldschule została założona w 1910 r. przez pedagoga Paula Geheeba. Miała stać się przyczółkiem antyautorytarnego wychowania, zgodnie z teoriami

11 J. Fleischhauer, W. Hollersen, Kuck mal, meine Vagina, „Der Spiegel” 2010, nr 25, s. $42-43$.

12 Tamże.

13 C. Brand, Reformp Dagogik Nach Der Odenwaldschule Wie Weiter, Springer 2016, s. $56-58$. 
„,nowego oświecenia” i rozwijać u dzieci „osobowość i samodzielne myślenie”14. Stało to w sprzeczności do wówczas obowiązujących zasad dyscypliny i szacunku dla autorytetu nauczycielskiego. Szkoła jednak szybko zyskała popularność. Uczyły się tu dzieci lewicowej politycznej elity, m.in. syn pisarza Tomasza Manna, Klaus Mann, oraz syn byłego prezydenta Niemiec Richarda von Weizsaeckera. Jednym z uczniów Odenwaldschule w latach 50. i 60. był „czerwony Dany”- lider Ruchu 68', europoseł partii Zielonych Daniel Cohn-Bendit, który później sam okazał się mieć bardzo ambiwalentny stosunek do pedofilii ${ }^{15}$.

Kiedy dzisiaj pyta się o te sprawy przywódców ruchu z końca lat sześćdziesiątych, udzielają oni niezdecydowanych lub wymijających odpowiedzi. Z perspektywy czasu Wolfgang Kraushaar, politolog i kronikarz tego ruchu stwierdził, że „istotą ruchu z $1968 \mathrm{r}$. był w istocie brak poszanowania koniecznych granic między dziećmi a dorosłymi. Zakres w jakim to prowadziło do przypadków nadużyć, jest dzisiaj całkowicie niejasny"16. Brak szacunku dla jakichkolwiek granic był bardzo wyraźny. Można również powiedzieć, że granice te zostały gwałtownie i całkowicie otwarte.

Wyzwolenie seksualne było jednym z priorytetów rewolucjonistów, którzy już w 1967 r. zaczęli wywracać społeczeństwo do góry nogami. Kontrola pożądania i popędu seksualnego była postrzegana jako narzędzie dominacji. Radykałowie tego ruchu wierzyli, że tylko ci, którzy wyzwolą się z represji seksualnych mogą być naprawdę wolni.

Wydawało się dla nich oczywiste, że owo wyzwolenie powinno rozpocząć się już w młodym wieku. Byli przekonani, że lepiej jest zapobiegać rozwojowi zahamowań seksualnych. Na przykład Revolution der Erziehung oder Erziehung zur Revolution? (Rewolucja edukacji czy edukacja dla rewolucji?), dzieło opublikowane przez Rowohlt Verlag w 1971 r., które szybko stało się bestsellerem, dotyka tematu seksualności w następujący sposób: „Deerotyzacja życia rodzinnego, zakaz seksualnej aktywność wśród dzieci i tabu kazirodztwa służy jako przygotowanie do wrogiego traktowania przyjemności seksualnej i jednoczesnego podporządkowania się nieludzkiemu systemowi pracy"17.

14 Tamże, s. 34.

15 Tamże, s. 89-90.

16 J. Fleischhauer, W. Hollersen, Kuck mal, meine Vagina, „Der Spiegel” 2010, nr 25, s. 45 .

17 T. Teo, Klaus Holzkamp and the Rise and Decline of German Critical Psychology, „History of Psychology” 1998, nr 1, s. 252. 


\section{Rewolucja trwa}

Z czym dzisiaj kojarzona jest rewolucja seksualna roku 1968? Tak radykalny efekt rewolucji seksualnej przedstawiony bardzo skrótowo w tym artykule (literatura podaje znacznie więcej przykładów) zdaje się być dzisiaj świadomie pomijany. Jednak nie można chyba mieć wątpliwości co do tego, że taki sposób myślenia wdrażany również w praktyce edukacyjnej niewątpliwie musiał wpływać na pojęcie wychowania, rodziny, seksualności i płci, a konsekwencje są widoczne po dzień dzisiejszy.

Kiedy papież emeryt Benedykt XVI w swoim artykule z 11 kwietnia 2019 r. na łamach niemieckiego pisma Klerusblatt upatrywał źródło pedofilii (i to nie tylko w Kościele katolickim) m.in. w ruchu końcówki lat 60 . i wspominał o tym, że głosił on też wyzwolenie seksualne, dopuszczające współżycie seksualne z dziećmi, jakże wiele osób oburzało się na te słowa. Ale przecież prof. Joseph Ratzinger był wtedy w centrum tych wydarzeń jako m.in. wykładowca akademicki. Widział na własne oczy, do czego prowadzi ten ruch i jakie ma zamiary.

Czy dzisiaj możemy mówić, o tej rewolucji seksualnej w czasie przeszłym? Jeżeli spojrzy się głębiej, zauważymy, że osoby wychowane na tym ruchu i w tym ruchu są dzisiaj nierzadko osobami decyzyjnymi na różnych poziomach społecznych, osobami mającymi wpływ na formowanie i tworzenie prawa. Są osobami tworzącymi teorie i ideologie. Psychologowie i seksuologowie niemieccy lat 70. i 80. oddziaływali w istotny sposób na badaczy z innych krajów i kontynentów. Osobiście uważam, że nie można mówić o rewolucji seksualnej końca lat 60. jako wydarzeniu historycznym chyba, że w takim sensie, że rozpoczęło się w tamtym czasie i trwa w różnych formach i z różnym nasileniem po dzień dzisiejszy. Dlatego kiedy zastanawiamy się czasami skąd się wziął dzisiejszy ambiwalentny stosunek (a może nawet atak?) co do wartości rodzinnych, co do małżeństwa jako związku kobiety i mężczyzny, co do wartości i pojęcia płci, to uważam, że warto, a nawet trzeba powrócić do końcówki lat 60 . XX w.

Rewolucja trwa! Dzisiaj jest bardzo subtelna, dziś jest bardziej inteligentna. Nauczyła się na swoich własnych błędach: gra w otwarte karty nie przyniesie zwycięstwa. Jednak mechanizm jest ten sam: w imię wolności rozumianej tylko i wyłącznie jednostronnie, dzisiaj powiedzielibyśmy podprogowo, prowadzona jest jej propaganda.

Jak się przeciwstawiać tejże rewolucji? Poprzez formację. Jednak rzetelna formacja musi zakładać rzetelną informację. Trzeba informować, żeby potem móc rzetelnie formować. I działać już nie z determinacją, ale zapożyczając słowa od św. Teresy od Jezusa: działać ze zdeterminowaną determinacją. 


\title{
Bibliografia
}

Becker W., Leisner U., Man musste blonde weiber haben, „Der Spiegel” 1970, nr 16, s. 99.

Brand C., Reformp Dagogik Nach Der Odenwaldschule Wie Weiter, Springer 2016. Fleischhauer J., Hollersen W., Kuck mal, meine Vagina, „Der Spiegel” 2010, nr 25, s. $40-45$.

Teo T., Klaus Holzkamp and the Rise and Decline of German Critical Psychology, „History of Psychology” 1998, nr 1, s. 235-253.

\section{Patryk HALAJCZAK: The sexual revolution and children}

\begin{abstract}
Summary
Speaking of the consequences and influences of the so-called sexual revolution of 1968, we should also mention children who were sometimes officially revolutionized systemically. At the end of the $1960 \mathrm{~s}$, as a programmatic effect of the German movement of 1968, the children's sexual liberation under the leadership of the Berlin Institute of Psychology. In practice, centers were set up with the aim to be upbringing over sexual inhibitions trying to create a climate in which even pedophilia was considered progressive. Some political regimes after 1968 affect the understanding of sexuality. Sexologists from Germany from the 1970s and 1980s had a real influence on researchers from these fields from other countries. Such a radical effect of the sexual revolution, which turns out to be deliberately neglected today, undoubtedly influenced the concept of education, family, sexuality and gender. The consequences are visible to this day.
\end{abstract}

Keywords: sexual revolution, sexuality, upbringing, education 